\title{
Türkiye'de İzole Edilen Francisella tularensis Alt Türlerinin Moleküler Yöntemlerle Belirlenmesi
}

\section{Determination of the Subspecies of Francisella tularensis Isolated in Turkey by Molecular Methods}

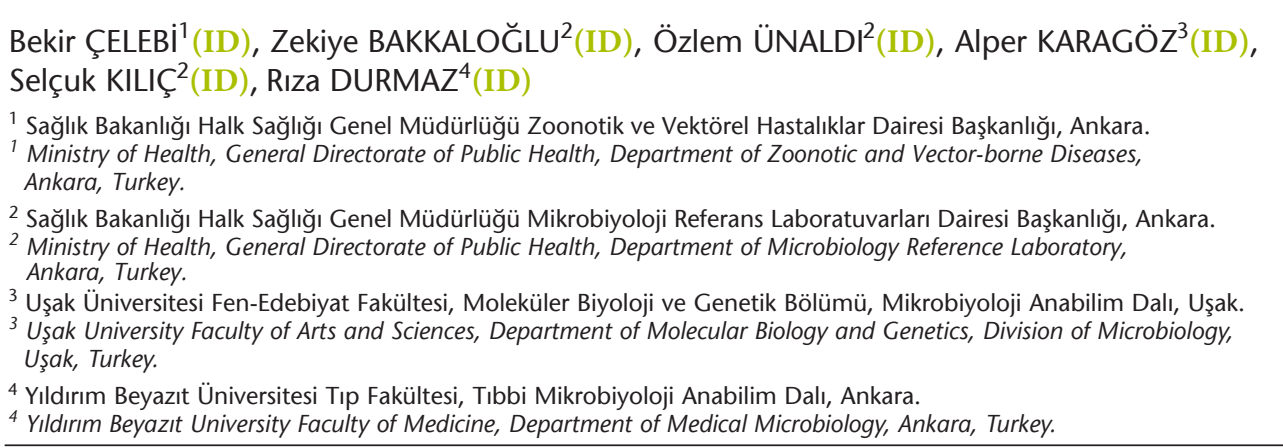

Makale Atıfı: Çelebi B, Bakkaloğlu Z, Ünaldı Ö, Karagöz A, Kılıç S, Durmaz R. Türkiye'de izole edilen Francisella tularensis alt türlerinin moleküler yöntemlerle belirlenmesi. Mikrobiyol Bul 2020;54(1):1-10.

\section{ÖZ}

Francisella tularensis, gram-negatif, kokobasil şeklinde olan fakültatif hücre içi bakteridir. İnsanlarda zoonotik bir hastalık olan tularemiye neden olur. F.tularensis alt tür tularensis, F.tularensis alt tür holarctica, F.tularensis alt tür mediasiatica ve F.tularensis alt tür novicida olmak üzere insanlarda virülansı farklı dört alt tür içermektedir. F.tularensis alt tür tularensis virülansı en yüksek alt tür olup neden olduğu olgularda mortalite oranı yüksektir. Ülkemizde bugüne kadar bildirilmiş olan F.tularensis alt tür holarctica'nın virülansı, alt tür tularensis'e göre daha düşük olup tedavi edilmeyen hastalarda ölüm nadiren görülmektedir. Eritromisin direnci, glikoz-gliserol fermentasyon özelliklerine göre F.tularensis alt tür holarctica'nın biovar I, biovar II ve biovar japonica olmak üzere üç biovarı bulunmaktadır. F.tularensis alt tür mediasiatica yalnız Orta Asya ülkelerinin birkaçında bildirilmiş olup virülansı F.tularensis alt tür holarctica'ya benzerlik göstermektedir. F.tularensis alt tür novicida immün sistemi yeterli bireyler için avirülan olup bağışıklık sistemi baskılanmış bireylerde enfeksiyona neden olduğu gözlenmiştir. Bu çalışmada, 2009-2014 yılları arasında klinik örneklerden, içme sularından ve bir kemiriciden elde edilen toplam 259 adet F.tularensis izolatının ve klinik örneklerde polimeraz zincir reaksiyonu (PCR) ile F.tularensis DNA'sı pozitif bulunan 517 örneğin ait olduğu alt türün belirlenmesi amaçlanmıştır. F.tularensis'in RD1 (Region Difference) bölgesine özgül primerler kullanılarak konvansiyonel PCR uygulanmıştır. PCR amplifikasyon ürününün büyüklüğündeki farkııı̆a bağlı olarak alt türler arası ayrım yapılmıştır. Çalışmamızda 764 örneğin, 922 baz çift (bp) amplifikasyon ürünü veren F.tularensis alt tür holarctica olduğu gözlenmiştir. Örneklerimizden, bir su izolatı ve 
11 lenf aspiratından elde edilen DNA örneğinin F.tularensis alt tür holarctica biovar japonica'ya ait olduğu belirlenmiştir. Su izolatının RD1 bölgesine ait amplifikasyon ürününe yönelik DNA dizi analizi yapılmışır. DNA dizi analizinden elde edilen 1136 bp dizilimi Genbank verileri ile karşılaştıııldığında, F.tularensis alt tür holarctica biovar japonica (FCS075 strain-erişim numarası AF469618) ile \%100 uyumlu bulunmuştur. Bu izolatın tüm genom sekansı da yapılarak GenBank'a kayıt edilmiş ve CP007148 erişim numarası alınmıştır. Çalışmamızda kullanılan örneklerin hiçbiri diğer alt türlere ait çıkmamıştır. F.tularensis alt tür holarctica biovar japonica pozitif belirlenen 11 lenf aspiratı örneği merkezimize Ankara $(n=1)$, Kayseri $(n=$ 1) ve Afyon $(n=9)$ illerinden gönderilmiştir. Bu çalışmanın sonuçları, ilk defa F.tularensis alt tür holarctica biovar japonica'nın Afyon ilinde bir köyde tularemi salgınına neden olduğunu ve farkı iki ilde de sporadik olarak gözlendiğini ortaya koymuştur.

Anahtar kelimeler: Francisella tularensis; alt türler; biovar japonica.

\section{ABSTRACT}

Francisella tularensis is a gram-negative, coccobacillus, facultative intracellular bacteria and causes a zoonotic disease, tularemia in humans. F.tularensis has four subspecies, which have different virulences for humans as F.tularensis subsp. tularensis, F.tularensis subsp. holarctica, F.tularensis subsp. mediasiatica and F.tularensis subsp. novicida. F.tularensis subsp. tularensis is the most virulent subspecies and mortality rate is high in human cases. F.tularensis subsp. holarctica, which has been reported in our country to date, has lower virulence than that of subsp. tularensis, and causes rare lethality among untreated patients. According to the erythromycin resistance and the properties of glucose-glycerol fermentation, F.tularensis subsp. holarctica has three biovar as biovar I, biovar II and biovar japonica. F.tularensis subsp. mediasiatica has been reported only in a few central asian countries and its virulence is similar to the F.tularensis subsp. holarctica F.tularensis subsp. novicida is avirulent for immunocompetent individuals but has been observed to cause infection in immunocompromised individuals. The aim of this study was to determine the F.tularensis subspecies in 259 F.tularensis strains isolated from clinical specimens, drinking water and a rodent sample and 517 F.tularensis PCR-positive DNA isolated from clinical specimens between years 2009 and 2014. Conventional PCR was performed using primers specific for the RD1 (Region Difference) region of F.tularensis. Subspecies were differentiated depending on the difference in PCR amplification product size. In our study, F.tularensis subsp. holarctica was detected in 764 samples yielding 922 base pair (bp) amplification product. The DNA samples obtained from one water and 11 lymph aspirates were determined as F.tularensis subsp. holarctica biovar japonica. The DNA sequence analysis of the amplification product of the RD1 region of the isolate from water sample was determined. The 1136 bp nucleotide sequence obtained from the DNA sequence analysis was $100 \%$ similar to F.tularensis subsp. holarctica biovar japonica (FCS075 strain-accesion number AF469618) when compared with GenBank data. The whole genome sequence of this isolate was also determined and recorded to GenBank with accesion number CP007148. None of the samples used in our study belonged to other sub-species. F.tularensis subsp. holarctica biovar japonica positive 11 lymph aspirate samples were sent to our center from Ankara ( $n=$ $1)$, Kayseri $(n=1)$ and Afyon $(n=9)$ provinces. The results of the current study revealed that F.tularensis subsp. holarctica biovar japonica caused a tularemia outbreak in a village in Afyon province at first time and it was observed sporadically in two other different provinces.

Keywords: Francisella tularensis; subspecies; biovar japonica.

\section{Gíriş}

Francisella tularensis gram-negatif, kokobasil şeklinde, fakültatif hücre içi bakteridir. İnsanlarda farklı klinik tablolarla kendini gösteren, zoonotik hastalık olan tularemiye neden olmaktadır. Etken doğada birçok hayvanda belirlenmişken, temel rezervuarı ve vektörleri yabani tavşanlar, birçok kemirici türü, keneler ve bazı sokucu sinekler olduğu bildirilmiş$\operatorname{tir}^{1,2}$. Etkenin insanlara bulaşması, enfekte hayvanlara temas veya enfekte hayvanların 
etlerinin tüketilmesi, bu hayvanların kontamine ettiği suların kullanılması, aerosolize olmuş etkenin solunum yolu ile alınması ve vektör konumundaki kene ve sokucu sineklerle ısırılma yolu ile olmaktadır². Ülkemizde enfeksiyon kaynağının çoğunlukla kırsal alanlardaki kontamine içme ve kullanma suları olduğu belirlenmiştir ${ }^{3-6}$. F.tularensis, kategori A biyoterör ajanları arasında yer almaktadır ve virülansları farklı olan F.tularensis alt tür tularensis, F.tularensis alt tür holarctica, F.tularensis alt tür mediasiatica ve F.tularensis alt tür novicida olmak üzere dört alt tür içermektedir ${ }^{7}$. F.tularensis alt tür tularensis insanlar için virülansı en yüksek alt tür olup neden olduğu tifoidal formu hastalarda \%30-60 arasında değişen mortalite oranına sahiptir. İnsanlarda enfektif doz olarak 10-15 bakterinin aerosol yolla veya subkutan yolla alınmasının yeterli olduğu bildirilmiştir ${ }^{2}$. Doğada tavşanlar rezervuar, keneler ve geyik sinekleri vektör konumundadır. F.tularensis alt tür holarcti$c a$ virülansı alt tür tularensis'e göre daha düşük olup tedavi edilmeyen hastalarda ölüm nadiren görülmektedir ${ }^{1,7}$. Eritromisin direnci, glukoz-gliserol fermentasyon özelliklerine göre F.tularensis alt tür holarctica'nın biovar I, biovar II ve biovar japonica olmak üzere üç biovarı bulunmaktadır ${ }^{2,8}$. Doğada bu alt tür için daha çok kemiriciler rezervuar, sivrisinek ve keneler vektör olarak bildirilmektedir. Bu alt türün insanlara bulaşmasında kontamine içme ve kullanma suları önemli rol oynamaktadır ${ }^{7}$. F.tularensis alt tür mediasiatica yalnız Orta Asya ülkelerinden bildirilmiş olup virülansı F.tularensis alt tür holarctica'ya benzerlik göstermektedir ${ }^{9}$. F.tularensis alt tür novicida immün sistemi yeterli bireyler için avirülan olup immün sistemi yetersiz bireylerde enfeksiyona neden olduğu gözlenmiştir. F.tularensis alt tür novicida'nın alt tür olarak değil de Francisella cinsinin bir türü olarak değerlendirilmesi tartışılmaktadır ${ }^{7}$. F.tularensis alt türlerinin ayrımı, önceleri biyolojik ve biyokimyasal özelliklerine göre yapılırken moleküler tekniklerin geliştirilmesiyle moleküler yöntemler ile yapılmaya başlanmıştır ${ }^{8,10-13}$.

Ülkemizde tularemi ilk kez 1936 yılında tespit edilmiş olup günümüze kadar birçok tularemi salgını bildirilmiştir ${ }^{1,14,15}$. Ülkemizde son yıllarda laboratuvar tanı imkanlarının gelişmesi sonucu klinik ve çevresel örneklerden F.tularensis'in izolasyonuna ve moleküler yöntemlerle tespitine yönelik çalışmalar yapılmıştır. F.tularensis'in virülansı farklı olan alt türlerinin tanımlanmasına yönelik çalışmalarda kısıtlı sayıda örnekten alt tür tanımlaması bildirilmiştir ${ }^{4,5,16-18}$.

Bu çalışmada, moleküler yöntemler kullanılarak, ülkemizin değişik bölgelerinden sağlanan klinik ve çevresel örneklerden elde edilen F.tularensis izolatlarının ve klinik örneklerde F.tularensis polimeraz zincir reaksiyonu (PCR) pozitif DNA'ların hangi alt türe ait olduğunun belirlenmesi amaçlanmıştır.

\section{GEREÇ ve YÖNTEM}

\section{F.tularensis İzolatlarının DNA İzolasyonu}

Tularemi referans laboratuvarına çeşitli illerden (Resim 1) gönderilen klinik ve çevresel örnekler kültür işlemine alındı. Klinik örnekler antibiyotikli, \%9 at kanlı, sistein kalp infüzyon agara direkt inoküle edilerek $\% 5 \mathrm{CO}_{2}{ }^{\prime l i}$ ortamda inkübasyona bırakıldı. Çevresel 


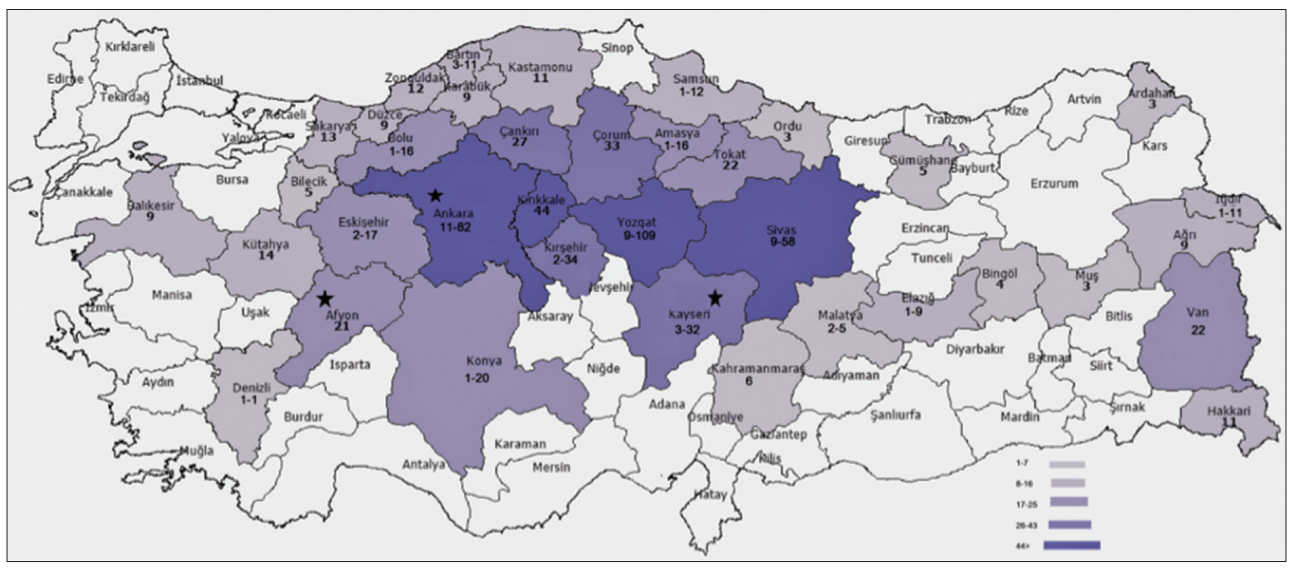

Resim 1. Çalışmada kullanılan F.tularensis izolatlarının ve pozitif DNA'ların elde edildiği klinik örneklerin il bazında dağılımı ve kullanılan pozitif örnek sayılarını içeren resim. illerin altında çalışmada kullanılan örnek sayıları çevresel-klinik örnek olarak ayrılmıştır. *F.tularensis subsp. holarctica biovar japonica pozitif belirlenen iller yıldız ile işaretlenmiştir.

örnekler (içme ve kullanma suları) $0.45 \mu \mathrm{m}$ selüloz nitrat membran filtrelerden (Sartorius AG, Goettingen, Almanya) geçirildikten sonra filtreler antibiyotikli, \%9 at kanlı, sistein kalp infüzyon agara ekildi ${ }^{19}$. Üremeler 10 günlük inkübasyon süresince değerlendirildi. Üremeler koloni morfolojisi ve üreme zamanına göre değerlendirildi. Şüpheli koloniler F.tularensis antiserum ile lam aglütinasyon yöntemiyle incelendi. Pozitif örneklerden DNA ekstraksiyonu kaynatma yöntemiyle yapıldı. Elde edilen DNA'lara TUL4 primerleri kullanılarak konvansiyonel PCR uygulandı ${ }^{20}$. Jel elektroforezde 420 baz çifti (bp) PCR amplifikasyon ürününün gözlenmesi F.tularensis PCR pozitif olarak değerlendirildi. Üreme olmayan klinik örneklerden (lenf aspiratı-doku biyopsi örneği) doku ekstraksiyon kiti (Qiagen Hilden, Almanya) kullanılarak DNA ekstraksiyonu yapıldı ve konvansiyonel PCR uygulandı. F.tularensis PCR pozitif olarak belirlenen DNA örnekleri $-20^{\circ} \mathrm{C}^{\prime}$ de derin dondurucuda saklandı. Bu çalışmada 2009-2014 yılları arasında çevresel ve klinik örneklerden kültür sonucu elde edilen F.tularensis izolatlarının tamamı ve klinik örnek olarak gönderilen, kültüründe üreme gözlenmeyen, PCR pozitif olan lenf aspiratı örneklerinin tamamından elde edilmiş DNA'lar kullanılmıştır.

\section{F.tularensis Alt Türlerinin PCR ile Belirlenmesi}

İzolatlardan ve lenf aspiratlarından elde edilen F.tularensis pozitif DNA'ların hangi alt türlere ait olduğunu belirlemek için, Broekhuijsen ve arkadaşlarının tanımladığı RD1 (Region Difference) bölgesine ait ileri 5' $5^{\prime}$ Tा ATA TAG GTA AAT GTT TTA CCT GTA CCA-3' ve ters 5'-GCC GAG TTT GAT GCT GAA AA-3' primerleri kullanılarak konvansiyonel PCR uygulan$\mathrm{d}^{12}$. PCR karışımı, $5 \mu$ l Hotstart Taq polimeraz reaksiyon tamponu, $4 \mu \mathrm{l}(25 \mathrm{mM}) \mathrm{MgCl}_{2^{\prime}} 1$ $\mu \mathrm{l}(10 \mathrm{mM}) \mathrm{dNTP}$, birer $\mu \mathrm{l}(10 \mathrm{pikomol} / \mu \mathrm{l})$ primerler, $0.25 \mu \mathrm{l}(5 \mathrm{lU} / \mu \mathrm{l})$ Hotstart Taq polimeraz enzimi, $32.75 \mu \mathrm{l}$ moleküler su ve $5 \mu$ l DNA örneği ile toplam hacim $50 \mu$ l olacak şekilde hazırlandı. Amplifikasyon koşulları $95^{\circ} \mathrm{C} 15$ dakika ön denatürasyonun ardından $95^{\circ} \mathrm{C} 30$ saniye denatürasyon, $60^{\circ} \mathrm{C}^{\prime}$ de 30 saniye bağlanma, $72^{\circ} \mathrm{C}^{\prime}$ de 1 dakika uzama olacak şekilde 
35 döngü ve $72^{\circ} \mathrm{C}^{\prime}$ de 5 dakika son uzama şeklinde uygulandı. PCR amplifikasyon ürünleri \%1.5 agaroz jelde yürütülerek değerlendirildi. Broekhuijsen ve arkadaşları $^{12}$ alt türler için, F.tularensis alt tür tularensis 1522 bp, F.tularensis alt tür holarctica 922 bp, F.tularensis alt tür mediasiatica 1453 bp, F.tularensis alt tür novicida 3322 bp ve F.tularensis alt tür holarctica biovar japonica 1135 bp uzunluğunda amplifikasyon ürünü gözlendiğini bildirmişlerdir. Çalışmamızda F.tularensis alt tür tularensis Schu4 suşu ve F.tularensis alt tür holarctica LVS suşu (NCTC 10857) DNA'ları pozitif kontrol olarak kullanıldı. Elektroforez değerlendirmesinde mevcut pozitif kontrollerin amplifikasyon ürünü uzunluğundan farklı amplifikasyon ürünleri gözlendiğinde, literatürde verilen amplifikasyon uzunluklarına göre değerlendirildi ve doğrulama için DNA dizi analizi ve tüm genom dizilemesi uygulandı.

\section{DNA Dizi Analizi}

Doğrulama için sadece su izolatına DNA dizi analizi ve tüm genom sekanslaması uygulandı. PCR amplifikasyon ürünlerini saflaştırmak için, Agencourt Ampure saflaştırma kiti (Beckman Coulter, Beverly, ABD) kullanıldı. Beckman Coulter 8000 Sanger dizileme cihazı (Beckman Coulter, Beverly, ABD) ve Dye Terminator Dizileme Kiti (Beckman Coulter, Beverly, ABD) kullanılarak çift yönlü nükleotit dizisi elde edildi. DNA dizi analizi verileri Basic Local Alignment Search Tool (Blast version 2.0) programı kullanılarak GenBank verileri ile karşılaştırıldı.

\section{Tüm Genom Dizileme}

Genomik DNA konsantrasyonu Qubit 2.0 florometri cihazı ile Qubit dsDNA HS (High Sensitivity) kiti kullanılarak ölçüldü ve yeni nesil dizileme uygulamalarında gerekli başlangıç genomik DNA miktarı 100 ng olacak şekilde ayarlandı. Yarı iletken temelli tüm genom dizileme "Ion Personal Genome MachineTM (PGM)" sistemi (Thermo Fisher Scientific, $A B D$ ) kullanılarak üretici firmanın yönergelerine göre yapıldı. Tüm genom kütüphanesi oluşturmak için gerekli enzimatik fragmantasyon ve adaptör ligasyonu "Ion Xpress Plus fragment library kit" (Life Technologies, CA, ABD) kullanılarak gerçekleştirildi. 200 bp okuma yapabilmek için hedeflenen 350 bp büyüklüğündeki DNA fragmanları, agaroz jel elektroforezi yöntemi ile "E-Gel ${ }^{\circledR}$ SizeSelect 2\%" (Invitrogen, Thermo Fisher Scientific, ABD) kiti ile belirlendi. Hazırlanan genomik kütüphane konsantrasyonu 100 pM olacak şekilde sulandırılıktan sonra kalıp hazırlama, emülsiyon PCR ve iyon küre partikülleri (ion sphere particle-ISP)'nin zenginleştirilmesi reaksiyonlarını gerçekleştirmek için "Ion One Touch 200 Template kit v2" (Life Technologies, CA, ABD) kullanıldı. Ion PGM 200 Sequencing kit (Life Technologies, CA, ABD) kullanılarak dizileme reaksiyonu ve yürütme işlemi Ion 314 çip üzerinde üretici firmanın yönergeleri doğrultusunda yapıldı. Yeni nesil dizileme verilerini analiz etmek, hizalamak ve birleştirmek için CLC Genomics Workbench 7.0 programı kullanıldı (CLC Bio,Qiagen, Aarhus, Danimarka).

\section{BULGULAR}

Bu çalışmada, 2009-2014 yılları arasında, klinik örneklerden, içme sularından ve Microtus guentheri isimli bir kemiriciden izole edilen toplam 259 F.tularensis izolatı ve klinik ör- 
neklerde F.tularensis PCR pozitif 517 DNA kullanılmıştır. Kullanılan izolatların hangi klinik örnekten izole edildiği Tablo I'de, izolatların ve klinik örneklerden elde edilen F.tularensis DNA'larının hangi illerden sağlandığı, hangi ile ait kaç pozitif örnek kullanıldığı, pozitif örnek yoğunluğuna bağlı olarak harita renklendirilerek Resim 1'de verilmiştir. Sayı belirtilmeyen ve renklendirilmeyen illerden moleküler çalışmalarda kullanılabilecek örnek gelmediği için boş bırakılmıştır.

RD1 primerleri kullanılarak uygulanan konvansiyonel PCR amplifikasyon ürünleri jel elektroforezde yürütülerek değerlendirilmiştir. Kullandığımız iki alt türe ait pozitif kontrollerimiz, F.tularensis alt tür tularensis 1522 bp, F.tularensis alt tür holarctica 922 bp uzunluğunda amplifikasyon ürünü vermiştir (Resim 2). Çalışmamızda 764 örneğin, 922 bp amplifikasyon ürünü veren F.tularensis alt tür holarctica olduğu gözlenmiştir. Örneklerimizin 12'sinde yaklaşık 1150 bp uzunluğunda amplifikasyon ürünü belirlenmiş ve bu örneklerin kaynak literatür bilgisine göre F.tularensis alt tür holarctica biovar japonica olduğu düşünülmüştür. F.tularensis RD1 bölgesi PCR sonrasında 12 örneğin F.tularensis alt tür holarctica biovar japonica olduğuna karar verilmiştir (Resim 2). Tablo I. Çalısmada Kullanılan F.tularensis İolatlarının ve Pozitif DNA Örneklerinin Elde Edildiği Klinik
Örnekler

\begin{tabular}{|c|c|c|c|c|c|c|c|}
\hline \multicolumn{7}{|c|}{ F.tularensis izolatlarının elde edildiği klinik örnekler $(n=259)$} & \multirow{2}{*}{$\begin{array}{c}\begin{array}{c}\text { F.tularensis } \\
\text { DNA } \\
(\mathrm{n}=517)\end{array} \\
\begin{array}{c}\text { Lenf } \\
\text { aspiratı }\end{array}\end{array}$} \\
\hline $\begin{array}{l}\text { Lenf } \\
\text { aspiratı }\end{array}$ & $\begin{array}{c}\text { Boğaz } \\
\text { sürüntüsü }\end{array}$ & $\begin{array}{c}\text { Göz } \\
\text { konjunktival } \\
\text { sürüntüsü }\end{array}$ & $\begin{array}{c}\text { Kan } \\
\text { kültürü }\end{array}$ & $\begin{array}{c}\text { Yara } \\
\text { sürüntüsü }\end{array}$ & İçme suları & Kemirici & \\
\hline 68 & 135 & 6 & 2 & 1 & 46 & 1 & 517 \\
\hline
\end{tabular}

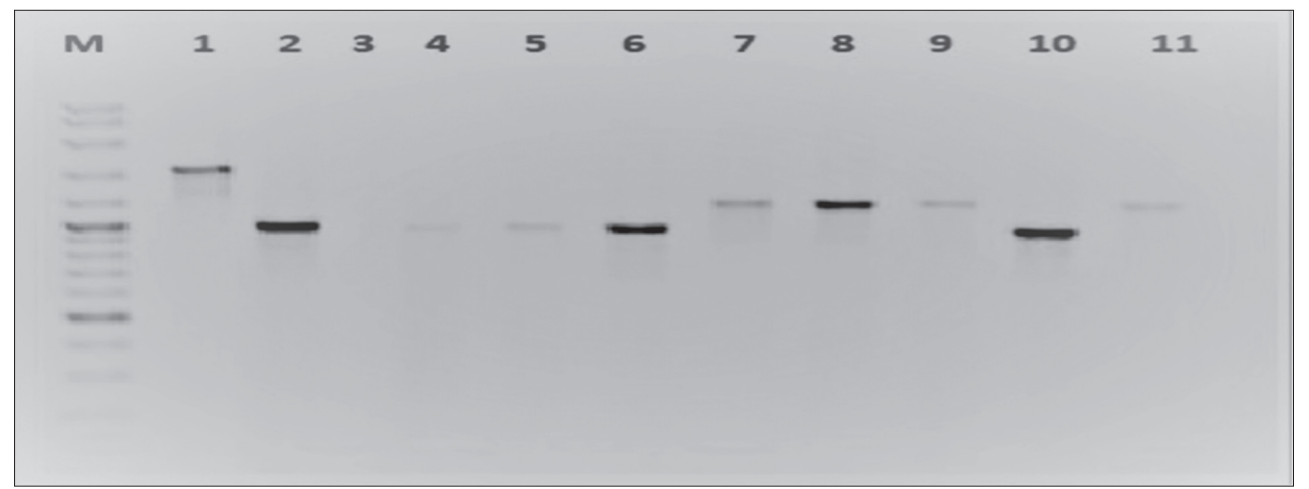

Resim 2. F.tularensis RD bölgesinin PCR amplifikasyon ürünlerinin jel elektroforezde görüntüsü. M: Moleküler ağırlık belirteci; 1: Pozitif kontrol F.tularensis subsp. tularensis (Shcu suşu) 1522 bp; 2: Pozitif kontrol F.tularensis subsp. holarctica (LVS suş NCTC 10857) 922 bp; 3: Negatif kontrol; 4,5,6,10: F.tularensis subsp. holarctica pozitif belirlenen klinik örnek DNA'ları; 7,8,9,11: F.tularensis subsp. holarctica biovar japonica pozitif belirlenen klinik örnek DNA'ları. 
Bu örneklerden bir tanesi su izolatından ve 11'i lenf aspiratından elde edilen DNA örnekleridir. Ankara Güdül ilçesi kırsal alanında sudan izole edilen örneğin RD1 bölgesi yaklaşık 1150 bp amplifikasyon ürününün DNA dizi analizi yapılmıştır. Çift yönlü yapılan DNA dizi analizinden elde edilen 1136 bp nükleotit diziliş Genbank verileri ile karşılaştırıldığında erişim numarası AF469618 F.tularensis alt tür holarctica biovar japonica (FCS075 suşu) ile \%100 uyumlu bulunmuştur. İzolatımıza ait nükleotit dizilimi GenBank'a kayıt edilerek JX436321 erişim numarası alınmıştır. Bu izolatın tüm genom dizilemesi de yapılarak GenBank'a kayıt edilmiş ve CP007148 erişim numarası alınmıştır. Çalışmamızda kullanılan örneklerin hiçbiri diğer alt türlere ait çıkmamıştır.

F.tularensis alt tür holarctica biovar japonica olarak belirlenen örneklerin ülkemizde lokalizasyon alanları değerlendirilmiştir. Su izolatımız Ankara Güdül ilçesinin kırsal alanında bölge halkı tarafından kısıtlı kullanımı olan fakat bir hastanın filyasyon çalışmasında içme kullanım suyu olarak kullandığını beyan ettiği bir kaynak suyundan izole edilmiştir. F.tularensis alt tür holarctica biovar japonica pozitif belirlenen 11 lenf aspiratı örneği Ankara $(n=1)$, Kayseri $(n=1)$ ve Afyon $(n=9)$ illerinden gönderilmiştir ve iller Resim 1'de yıldız ile işaretlenmiştir. Ülkemizde F.tularensis alt tür holarctica biovar japonica'nın Afyon ilinde bir köyde tularemi salgınına neden olduğu ve farklı iki ilde de sporadik olarak görüldüğü izlenmiştir.

\section{TARTIŞMA}

F.tularensis alt türlerinin virülans farklılıklarının yanında bulaş yolları, insanlarda ve hayvanlarda oluşturdukları klinik tabloları ve coğrafi lokalizasyonları da farklılık gösterebilmektedir. En virülan alt tür olan F.tularensis alt tür tularensis'in aerosol yolla bulaşmasıyla gelişen pnömonik tularemi formu ile kene ısırmasıyla gelişen tifoidal tularemi formunun mortalitesinin yüksek olduğu bildirilmiştir. Bu özelliğinden dolayı biyoterör etkeni kategorisinde değerlendirilmektedir ${ }^{2,7}$. Enfektif doz $50\left(E_{50}\right)^{\prime}$ nin insanlar, fareler, kobaylar ve tavşanlarda 10 bakteriden az olduğu bildirilmiştir. Coğrafi lokalizasyonu Kuzey Amerika kıtası olarak bildirilmektedir². Ancak 1998 yılında Slovakya'da pire ve akarlarda F.tularensis alt tür tularensis izolasyonu bildirilmiştir ${ }^{21}$. Daha sonra yapılan genotipik çalışmalarda bu izolatların Amerika Birleşik Devletleri'nde laboratuvarda elde edilen mutant Schu4 suşu ile uyumlu olduğu belirlenmiştir. Bu izolatların kaynağının insan eli ile bulaşma olduğu düşünülmektedir ${ }^{22}$. F.tularensis alt tür holarctica daha az virülan olup insanlara daha çok içme suları, sokucu sinekler ve keneler tarafından bulaşmaktadır ${ }^{2,7}$. Insanlarda oluşturdukları klinik form, bulaş yolu oral yol ise orofarengeal form ve takibinde ülseroglandüler forma dönüşen bir klinik tablo, kene veya sokucu sineklerle bulaş olmuşsa glandüler form şeklinde ortaya çıkmaktadır ${ }^{1}$. Ülkemizdeki olguların çoğu orofarengeal tularemi klinik tablosunda olup su kaynaklı enfeksiyonlar olduğu bildirilmiştir ${ }^{5,16,17}$. Nadiren kene kaynaklı glandüler tularemi klinik formu da bildirilmiştir ${ }^{23}$. F.tularensis alt tür holarctica'nın $\mathrm{ED}_{50}$ değeri fare ve kobaylar için 10 bakteriden azken insanlarda $10^{3}$ bakteriden az, tavşanlarda ise $10^{6}$ bakteriden fazla olduğu belirlenmiştir. Coğrafik lokalizasyonu kuzey yarım kürede Avrupa ve Asya'da daha yaygınken Kuzey Amerika'da daha az bildirilmiştir ${ }^{2}$. F.tularensis 
alt tür mediasiatica virülansı alt tür holarctica ile benzerlik göstermektedir. Orta Asya ülkelerinden Kazakistan, Türkmenistan, Özbekistan ve Rusya Federasyonu Altay bölgesinde bildirilmiş olup başka coğrafyalarda bildirime ilişkin bilgi bulunmamaktadır ${ }^{9}$. F.tularensis alt tür novicida bildirimi ise oldukça sınırlıdır². Ülkemizde F.tularensis alt türlerinin belirlenmesine yönelik çalışmalarda sınırlı sayıda örnek kullanılmıştır ${ }^{4,5,17,18}$. Gürcan ve arkadaşları ${ }^{18}$ "multiple-locus variable-number tandem repeat analysis (MLVA)" yöntemi ile iki izolatın F.tularensis alt tür holarctica olduğunu bildirmişlerdir. Kılıç ve arkadaşları ${ }^{4}$ "single nucleotide polymorphisms (SNP)" yöntemi ile 40 örnek çalışmışlar ve örneklerin F.tularensis alt tür holarctica olduğunu saptamışlardır. Söz konusu çalışmada 776 örnek konvansiyonel PCR yöntemi ile çalışılmış ve örneklerin hepsinin F.tularensis alt tür holarctica olduğu belirlenmiş̧ir.

F.tularensis alt tür holarctica'nın biovar I ( $E^{S}$-Eritromisin duyarlı), biovar II ( $E^{R}$ Eritromisin dirençli) ve biovar japonica $\left(\mathrm{E}^{S}\right)$ olmak üzere üç biovarı bulunmaktadır. Biovarlar eritromisin dirençlerine, glukoz ve gliserol fermentasyon özelliklerine göre ayrılmaktadır. Virülans farkları gözlenmemiştir. Coğrafi lokalizasyonlarına göre biovar I ve II kuzey yarım kürede dağılım gösterirken, biovar japonica'nın sadece bir ada ülkesi olan Japonya'da görüldüğü bildirilmektedir $2,7,10$. Bu çalışmanın başlangıcı ile 2011 yılında kaynak suyundan izole ettiğimiz PHIT-FT049 Güdül suşunun F.tularensis alt tür holarctica biovar japonica olduğu, 2012 yılında X. Ulusal Veteriner Mikrobiyoloji Kongresinde Çelebi ve arkadaşları ${ }^{24}$ tarafından sunulmuş ve böylece F.tularensis alt tür holarctica biovar japonica'nın Japonya ile sınırlı olmadığı ilk defa bildirilmiştir. Kılıç ve arkadaşları ${ }^{25} 2013$ yılında F.tularensis alt tür holarctica biovar japonica PHIT-FT049 Güdül suşunun antibiyotik duyarlılık testlerini çalışarak eritromisin duyarlılığını belirlemişlerdir. Wang ve arkadaşları ${ }^{26} 2014$ yılında SNP yöntemi ile F.tularensis alt tür holarctica biovar japonica'nın Çin'de de varlığını üç izolatla göstermişlerdir. Kılıç ve arkadaşları 2015 yılında SNP ve multilokus varyant analizi (MLVA) yöntemleri ile PHIT-FT049 Güdül suşunun Japonya izolatlarıyla benzerliğini ortaya koymuşlar ve filogenetik değerlendirmede Japonya izolatlarının Asya orijinli olma ihtimalini bildirmişlerdir. En son Eden ve arkadaşları 272017 yılında Avustralya'da bir izolasyon ile F.tularensis alt tür holarctica biovar japonica'nın varlığını belirlemişlerdir. Bu çalışmada, F.tularensis alt tür holarctica biovar japonica'nın ülkemizde Ankara, Kayseri ve Afyon illerinde toplam 12 örnekte tespit edilirken, insanlarda tularemi salgınına da neden olduğu gözlenmiştir.

F.tularensis alt türlerinin virülans farklılıklarına bağlı farklı klinik tablolar göstermeleri ve biyoterör etkeni de olmalarına bağlı olarak laboratuvar tanıları önemlidir. Laboratuvar tanısında antijenik yapılarının benzer olmasından dolayı serolojik olarak ayrılamamaktadırlar. Kültür işlemlerinde etkenin geç ve güç üremesinden dolayı her zaman izolasyon mümkün olmayabilir. İzolatların alt tür olarak tanımlanmalarında biyokimyasal testler ve deney hayvanı inokülasyonları yöntemleri kullanılmıştır ${ }^{2,7}$. Bu yöntemlerin uygulanması için donanımlı laboratuvar ve tecrübeli laboratuvar çalışanı gereksiniminin yanında bu yöntemlerin zaman alıcı süreçlerinin olması dezavantajları olarak ortaya çıkmaktadır. Moleküler tekniklerin gelişmesiyle, MLVA, SNP ve konvansiyonel PCR gibi moleküler yöntem- 
lerle daha hızlı alt tür tanımlamaları geliştirilmiştir. MLVA ve SNP yöntemleri izolatların genotipik özelliklerini moleküler epidemiyolojik verileriyle ortaya koyan yöntemlerdir ${ }^{7,22,28}$. Bu yöntemler maliyetli olup aynı zamanda biyoinformatik bilgisi ve teknik donanım ihtiyacı gerektirmektedir. F.tularensis alt türlerinin belirlenmesinde basit ve kolay bir yöntem olan konvasiyonel PCR yöntemi günümüzde birçok laboratuvarda kullanılabilecek bir yöntemdir. Bu çalışmada F.tularensis'in RD1 bölgesinin alt tür ayrım özelliğinden yararlanılarak konvansiyonel PCR yöntemi ile ülkemizdeki F.tularensis alt türlerinin belirlenmesine yönelik geniş kapsamlı bir çalışma yapılmıştır.

Ülkemizde belirlenen F.tularensis alt tür holarctica biovar japonica'nın bu coğrafyada gözlenmesinin nedeni üzerine yapılabilecek yorumların, bugünkü veriler ışı̆̆ında ihtimal düzeyinde olacağı düşünülmektedir. Küreselleşen dünyada, ticari faaliyetler, insan hareketleri, bunların paralelinde etkenin doğal rezervuarları olan kemiricilerin hareketleri etkenin yayılımına etki edebildiği gibi kasıtlı olarak insan eli ile salınımlar da söz konusu olabilir. Önemli bir patojen olan F.tularensis'in ülkemizdeki biyolojik döngüsünün, biyolojik ve genotipik özelliklerinin belirlenmesiyle neden olduğu hastalığa yönelik alınabilecek kontrol ve eliminasyon programlarına katkı sağlayabilmesi için bu konudaki çalışmaların devamının önemli olduğu düşünülmektedir.

\section{ÇIKAR ÇATIŞMASI}

Yazarlar bu makale ile ilgili herhangi bir çıkar çatışması bildirmemişlerdir.

\section{KAYNAKLAR}

1. Kılıç AU, Doğanay M. Tularemia: a re-emerging disease. Ankara Üniv Vet Fak Derg 2013;60:275-80.

2. Gürcan S. Epidemiology of tularemia. Balkan Med J 2014;31(1):3-10.

3. Aktas D, Celebi B, Isik ME, Tutus C, Ozturk H, Temel F, et al. Oropharyngeal tularemia outbreak associated with drinking contaminated tap water, Turkey, July-September 2013. Emerg Infect Dis 2015;21(12):2194-6.

4. Kilic S, Birdsell DN, Karagöz A, Çelebi B, Bakkaloglu Z, Arikan M, et al. Water as source of Francisella tularensis infection in humans, Turkey. Emerg Infect Dis 2015;21(12):2213-6.

5. Kılıç AU, Kılıç S, Sencan I, Sentürk GÇ, Gürüz Y, Tütüncü EE, et al. İç Anadolu Bölgesinde Francisella tularensis alt tür halorctica'ya bağlı su kaynaklı bir tularemi salgını. Mikrobiyol Bul 2011;45(2):234-47.

6. Boz A, Aktuna G, Özgülcü Ş, Sezgin B, Temel F, Çelebi B. Afyonkarahisar ili Dinar ilçesinde 2015 yılı Ocak ayında görülen tularemi vakaları. Turk Hij Den Biyol Derg 2016;73(3):233-44.

7. Keim P, Johansson A, Wagner DM. Molecular epidemiology, evolution, and ecology of Francisella. Ann N Y Acad Sci 2007;1105:30-66.

8. Sandström G, Sjöstedt A, Forsman M, Pavlovich NV, Mishankin BN. Characterization and classification of strains of Francisella tularensis isolated in the Central Asian focus of the Soviet Union and in Japan. J Clin Microbiol 1992;30(1):172-5.

9. Timofeev V, Bakhteeva I, Titareva G, Kopylov P, Christiany D, Mokrievich A, et al. Russian isolates enlarge the known geographic diversity of Francisella tularensis subsp. mediasiatica. PLoS One 2017:5;12(9):e0183714.

10. Olsufjev NG, Meshcheryakova IS. Subspecific taxonomy of Francisella tularensis McCoy and Chapin 1912. Int J Syst Bacteriol 1983;33(4):872-4.

11. Marchette NJ, Nicholes PS. Virulence and citrulline ureidase activity of Pasteurella tularensis. J Bacteriol $1961 ; 82: 26-32$. 
12. Broekhuijsen $M$, Larsson P, Johansson A, Byström M, Eriksson U, Larsson E, et al. Genome-wide DNA microarray analysis of Francisella tularensis strains demonstrates extensive genetic conservation within the species but identifies regions that are unique to the highly virulent F.tularensis subsp. tularensis. J Clin Microbiol 2003;41(7):2924-31.

13. Johansson A, Farlow J, Larsson $P$, Dukerich $M$, Chambers $E$, Byström $M$, et al. Worldwide genetic relationships among Francisella tularensis isolates determined by multiple-locus variable-number tandem repeat analysis. J Bacteriol 2004;186(17):5808-18.

14. Gotschlich E, Berkin T. 1936 yılında Trakya'da tularemiye ait yapılan epidemiyolojik ve bakteriyolojik araştırmalar. Türk Hij Den Biyol Derg 2007;64(1):71-5.

15. Celebi G, Baruönü F, Ayoğlu F, Cinar F, Karadenizli A, Uğur MB, et al. Tularemia, a reemerging disease in northwest Turkey: epidemiological investigation and evaluation of treatment responses. Jpn J Infect Dis 2006;59(4):229-34.

16. Uyar M, Cengiz B, Ünlü M, Çelebi B, Kılıç S, Eryılmaz A. Orta Anadolu Bölgesi illerinden hastanemize basvuran orofaringeal tularemi olgularının değerlendirilmesi. Mikrobiyol Bul 2011;45(1):58-66.

17. Akıncı E, Ülgen F, Kılıç S, Alıravcı D, Çelebi B, Eren SS, et al. Orta Anadolu kaynaklı tularemi olgularının değerlendirilmesi. Mikrobiyol Bul 2011;45(4):762-4.

18. Gurcan S, Karabay O, Karadenizli A, Karagol C, Kantardjiev T, Ivanov IN. Characteristics of the Turkish isolates of Francisella tularensis. Jpn J Infect Dis 2008;61(3):223-5.

19. Petersen JM, Carlson J, Yockey B, Pillai S, Kuske C, Garbalena G, et al. Direct isolation of Francisella spp. from environmental samples. Lett Appl Microbiol 2009;48(6):663-7.

20. Sjöstedt A, Eriksson U, Berglund L, Tärnvik A. Detection of Francisella tularensis in ulcers of patients with tularemia by PCR. J Clin Microbiol 1997;35(5):1045-8.

21. Gurycová D. First isolation of Francisella tularensis subsp. tularensis in Europe. Eur J Epidemiol 1998;14(8):797802.

22. Chaudhuri RR, Ren CP, Desmond L, Vincent GA, Silman NJ, Brehm JK, et al. Genome sequencing shows that European isolates of Francisella tularensis subspecies tularensis are almost identical to US laboratory strain Schu S4. PLoS One 2007:4;2(4):e352.

23. Yesilyurt M, Kılıç S, Çagasar Ö, Çelebi B, Gül S. Yozgat ilinde kene kaynaklı iki tularemi olgusu. Mikrobiyol Bul 2011;45(4):746-54.

24. Çelebi B, Kılıç S, Karagöz A, Durmaz R. Ülkemizde izole edilen Francisella tularensis izolatların alt türlerinin belirlenmesi. X. Ulusal Veteriner Mikrobiyoloji Kongresi, 24-27 Eylül 2012, Kuşadası/Aydın. Kongre Kitabı, s: 36-37, sözlü sunum 12.

25. Kiliç S, Çelebi B, Acar B, Atas M. In vitro susceptibility of isolates of Francisella tularensis from Turkey. Scand J Infect Dis 2013;45(5):337-41.

26. Wang Y, Peng Y, Hai R, Xia L, Li H, Zhang Z, et al. Diversity of Francisella tularensis subsp. holarctica lineages, China. Emerg Infect Dis 2014;20(7):1191-4.

27. Eden JS, Rose K, Ng J, Shi M, Wang Q, Sintchenko V, et al. Francisella tularensis spp. holarctica in ringtail possums, Australia. Emerg Infect Dis 2017;23(7):1198-201.

28. Vogler AJ, Birdsell D, Price LB, Bowers JR, Beckstrom-Sternberg SM, Auerbach RK, et al. Phylogeography of Francisella tularensis: global expansion of a highly fit clone. J Bacteriol 2009;191(8):2474-84. 